\title{
Application Of Strategic Marketing On Tourism Management In Nigeria
}

\author{
Virginia Benson-Eluwa \\ Department of Marketing, \\ Abia State University, Uturu, Nigeria
}

\begin{abstract}
The work is on concepts of strategic thinking that are central to the efficient conduct of marketing-led organizations in travel and tourism. It stresses on the competitive future orientation of strategy in an era of globalization, constant change and the redrawing of traditional industry sector boundaries facilitated by information technology. Tourism growth is generally rapid although at varying degrees depending on the level of attention given, to the industry and technological advancement in the country.
\end{abstract}

Key Words: Strategic marketing, Tourism management.

\section{INTRODUCTION}

The rapid development in technology and sciences has brought about unprecedented transformation in modern transportation and communication hardware that has turned the world not just to a global village but to one neighbourhood (Benson-Eluwa and Kajang, Joshua 2016). Tourism has become an important and widely accepted and practiced human activity globally. Importantly, the contribution of tourism sub-sector to the socio-cultural, economic and political development of most countries in both developed and developing blocs of the world is no longer an issue in contention.

Tourism had a global output of US\$ 4.2 trillion and employed about 192.2 million people making the subsector the largest employer in 2013 (Gilammia \& Mohammadi, 2015; Esu, 2015). Tourism subsector contributed directly to the Gross Domestic Product (GDP) of United States of America to the tone of USD 457. 9 billion, China 263 billion and Germany 112.4 billion dollars in 2014 - (WTTC report in Punch, Tuesday, June, 7, 2016).

Tourism generated 53 million jobs in USA, 28.4 million jobs in Germany, 23.1 million jobs in China and 18.9 million jobs in the United Kingdom in 2014. The Punch also revealed that one hundred million $(100 \mathrm{~m})$ Chinese tourists spent about one hundred and sixty four billion dollars ( $\$ 164 \mathrm{~b}$ ) in 2014. In Africa, South Africa, grossed $\$ 35.00$ billion; Morocco, $\$ 34.00$ billion; Namibia, $\$ 33.80$ billion; Kenya, $\$ 32.00$ billion; Tunisia, $\$ 31.80$ billion, while Nigeria trailed with a depressing $\$ 2.79$ million earnings! Indeed, Nigeria ranks 131 out of 141 countries with tourism competitiveness index in 2015 (Wikipedia free encyclopedia, in Muyiwa, 2016).

\section{MARKETING STRATEGY AND TOURISM MANAGEMENT RELATIONSHIP}

Marketing relationship partners may include end-user customers, marketing channel members, suppliers, competitor alliances, and internal teams. The driving force underlying these relationships is that a company may enhance its ability to satisfy customers and cope with a rapidly changing business environment through the collaboration of the parties involved. Relationship strategies gained new importance in the 1990s as customers became 'more demanding and competition became more intense. Building long-term relationships with customers and value-chain partners offers companies a way, to provide superior customer 
value. Although building collaborative relationships may not always be the best course of action, this avenue for gaining a competitive edge is increasing in popularity.

Treating the elements of the marketing mix in details and separately does not underscore the importance of their interdependence. One of the major problems involved in gaining a proper understanding of the nature of the marketing mix lies in its treatments in marketing literature. Authors tend to devote discrete each of the elements of the Four Ps, stressing initially on the product/service and then moving successively through price, promotion and place.

Based upon the sequence or starting point in a series of decision adopted in many organizations (country), the sequential treatment beginning with product, price, promotion and distribution can be justified, otherwise, it is important to recognize that decisions made with regard to one element of the marketing mix, inevitably affect other elements of the mix. Certainly product, promotion and place, all have cost implications to the consumer. The channel of distribution will affect both promotion and the product/service.

The interdependency that exists among the elements of the marketing mix and strategic marketing necessitate the need for these elements to be integrated in a harmonious manner to achieve the greatest possible attractiveness of the total mix to its target market segment. It would look ridiculous to advertize the Lexus car in Ikebe magazine. Such high-priced, highclass products such as Lexus or Rolls-Royce cars can only be purchased by particular members of the higher income bracket. Their promotion certainly has to be through reputable exclusive dealers. BMW cars are selectively marketed in Nigeria by COSCHARIS with their display office located in Victoria - Island. When the elements of the marketing mix are integrated, the chances for dissonance and confusion in messages disseminated to the target markets are drastically reduced. Services can also enjoy harmonious integrated elements of the marketing mix just like physical products. For instance, one of the long distance luxury bus operators added many new modern buses to his fleet. The fares were reasonable and competitive. They were among the lowest on their route and the frequency of service was excellent. Information on all the bus services were readily available. One would expect everything to go accordingly as the ingredients in the service mix look harmoniously integrated.

Marketing mix can also be seen as a means to an end according to supra authors. In other words, the marketing mix elements are a set of variable inputs to a process which are transformed to generate desirable results.

Marketing mix, information input should be drawn from marketing research to influence marketing decisions. It is therefore expected that product/service features should reflect identified customer needs and wants; advertising should be pre-tested to ensure impact and retention of desire - arousing messages; products should be properly placed in prime locations; accompanied by cost effective point-of-purchase display materials. From this perspective, strategic management of tourism will benefit Nigeria immensely as Nigeria is a country abounds with abundant natural and man-made tourist's products across the breadth and the length of the country. Nigeria's abundant tourism assets ranging from natural, historical, cultural and artificial attractions offer priceless opportunities for huge investment in the sector and other supportive services and can stimulate the economy productively.

But Nigeria with over 250 ethnic cultural diversity and other fascinating tourist products is not mentioned among the first ten destinations in Africa in 2013 (Esu, 2015). Research reveals that Egypt is the most visited country in Africa, Kenya and Tanzania are the most visited countries in East Africa, and Gambia and Senegal as the most visited countries in West Africa. In 2013 
Morocco, South Africa, Tunisia, Algeria, Mozambique, Zimbabwe, Kenya, Uganda, Swaziland and Tanzania are the top ten destinations in Africa. Morocco had 10 million international arrivals while the tenth Tanzania had I million international arrivals but Nigeria had 600 thousand international arrivals in 2013. Nigerian tourism poor performance is precarious (Esu, 2015).

Esu (2015) also, posits that poor product packaging, poor product quality, poor skilled and requisite labour in the sector, inadequate modern tourism infrastructure and facilities are the reasons for poor tourism performance in Nigeria. Most importantly and seriously is the unpredictable, dynamic and sophisticated business environment that is encouraging high consumer taste.

From the above assertions, tourism in Nigeria has been plunged with many internal and external marketing environmental forces that strategic marketing stands out as the panacea to address the industry. Thus, with the right marketing mix (product, price, place and promotion), strategic marketing has the propensity to re-position and reclaim the Nigerian tourism industry to be what it was known for in the previous years. Strategic marketing will introduce strategic approach to proper management of the tourism industry. Strategic marketing will introduce flexibility, adjustability and adaptability as well as predictable measures that will enable destination management organizations to meet up with challenges in the present tourism environment that characterized by many upheavals. Strategic marketing is a tool that is used to analyze environmental components, forces, competitors and predicting future trends in high interest areas of business.

World Tourism Organization (WTO) defines Tourism as the activities of a person travelling outside his or her usual environment for less than a specified period of time and whose main purpose of travel is other than the exercise and activity remunerated from the place visited (WTO, 1991).

Page (2006), views tourism as a temporary movement of persons away from their immediate home/communities and daily work environments for business, pleasure or personal reasons. In the same vein, Lic Korish and Jenkins (2003), view tourism as the sum of phenomena and relationships arising from the travel and stay of non residents in so far as they do not lead to permanent residence and are not connected to any earning activity.

On the other hand, strategic marketing as reviewed by Etuk (2003) is an aspect of marketing process that is concerned with ensuring that an organization (in this context, Destination Management Organization - DMO) is viable and its resources are adopted to its environment in a manner that permits efficient attainment of organizational stated goals using appropriate courses of actions within acceptable degree of risk. Achison (2002), reports that strategic marketing is concerned with interactions between firms and their environments as well as the interplay of major forces like customers, competitions and other organizations.

However, strategic marketing concentrates on future market trends to be observed and served, the competition to be confronted and appropriate timing of market entry and exit as well as related moves. It is concerned with building strong sustainable competitive position in selected market segment.

The marketing principles again apply to the whole economy and all economic activities. It is a golden role in marketing to know what business organization or individual is into. Marketing success is envitable when the focus of the company is customer oriented rather than product 
oriented. Thus, for business operators in tourism to be successful, they must be customer oriented.

Lickorish and Jenkins (2003), submit that understanding the business of tourism means appreciation of its unique characteristics or features, its strengths and weaknesses and in the case of the specific product, its unique advantages. This enables the manager to turn these unique advantages into unique selling proposition in the approach to the clientele.

Page and Connell again mentioned that most commercial organizations in the tourism industry aim to survive make reasonable profits and in many cases grow and expand. To achieve this, firm requires a strategic marketing approach to put in place a strategic marketing plan which is flexible and regular if not a constant feature of managerial activity. Strategic marketing is futuristic in approach and this serves demand need to plan for the future. Tourism Management Agencies need to be forward thinking and innovative while thinking about the markets they serve or will serve, thereby ensuring the organization is outward facing.

Venter (2009), posits that strategic marketing is supportive and enhance identification of tourism markets opportunities for competitive advantage, managing and marketing existing tourism products for customer satisfaction. Ebitu (2015), states that strategic marketing approach concentrates on the future rather than the present or immediate past.

Strategic marketing in its characteristics is futuristic, facilitates effective growth, builds and controls appropriate strategies for long term effective demonstrative management of tourism firms in the present dynamic, sophisticated and competitive business environmental pressures and treats. It calls for concentration on what business to be involved with, searching for new opportunities and achieving synergy among functional organs of organization both vertically and horizontally. Strategic marketing attempts to establish a fit between the organization and the environment. Thus, it entails matching the organization core values, competencies with the opportunities in the environment while creating substantial efforts to eliminate or at best to avoid the effects which its weakness and environmental threats could create in the organization.

\section{Advantages of Strategic economic marketing in tourism management}

1. To streamline organization activities Strategic marketing emphasis will enable tourism organizations to streamline activities towards essential external influences. This will assist the naton/organization to build or create a focus on market driven strategies that are strictly anchored to customer's needs satisfaction.

2. Anticipate changes in business environment: strategic marketing will enhance effective sustainable competitive position in the selected market segments, anticipation of changes in the business environment rather than tourism organizations to react only when challenges occur. It is predictive and enables the destination management to take long term view of the external environment. The ability of the management to penetrate the market shows that the marketing strategies adopted must have both internal and external influence in the industry.

3. Strategic marketing will compel decision to be taken about destinations plans on strategic alternative and choice

4. Strategic marketing assists tourism organizations to recruit and match products or markets with the right managers mix in order to achieve profitable high performance.

5. It enables and assists destinations management to properly and efficiently monitor and scan the environment, deciding which customer market segment it focuses, selling product specification and closing the rival to attack or avoid. 
6. It will provide tourism organizations with specific and authenticated direction. This enables the organization to focus on a particular choice among competing or alternative options.

7. It enables tourism organization to focus on long term view and make visible the resource allocation decision that is directed by accounting system, political strength or inertia.

8. It provides effective and efficient communication and coordination system for both horizontal and vertical line in tourism system, detects problems and strategically offer means to solve this problem within the organization.

9. Strategic marketing and future of tourism in Nigeria. It is obvious that destinations management organizations are charged with the responsibility to develops promote and sustain the growth of tourism in Nigeria. Unfortunately, the destination management organizations are yet to exploit tourism potentials to the nation's advantage and development significantly.

Page et al (2006) states that strategic marketing approach especially planning that is flexible and a regular feature of management activity must be put in place to ensure organization's growth, and survival as well as to satisfy the needs of the tourism. Strategic marketing attempts to analyze not just the available resources but the entire unpredictable marketing or business environment in order to chart a course of direction through prediction of the future. This strategic marketing enables the management of destinations or attractions to address their concern and have a specific tourism philosophy to pursue. Strategic marketing enables the organization to audit or identify the destination's strengths, weaknesses and ability to reach to opportunities and possible threats.

\section{SWOT Analysis}

Swot analysis provides the arsenals of strategy in business. It is an acronym for strengths, weaknesses, opportunities and threats. SWOT analysis offers a platform for firm to assess and identify their position within the market in connection to composition in the market. SWOT analysis has two components internal and external components. The strengths and weaknesses are the internal, components. This refers to the advantages and short coming in the provision of tourism products, the physical evidence, the people in the organization and the quality of services delivered especially during moments of truth. (Kotler, Bowen \& Markens, 2010). The firm financial position has a strong place in the determination of the strength of the firm as well as assets amongst others. Opportunities and threats are external components. Opportunities refers to these areas of needs that are yet to be addressed and met that an organization can provide and satisfy the target market while threats are these obstacles that impede the growth and operations of the firm.

Thus, opportunities include nature of the market, new technology available, favourable economic opportunities while threats may be in form of unfavourable government policies, political crises and instability, culture deficiencies and unfavourable legal framework. In essence SWOT analysis is very virtue to the tourism destinations.

\section{Importance of Tourism in Nigeria}

Adora (2010). States that tourism importance is manifested in the following ways, namely:-

a. Stimulates the exchange of educational, recreational and cultural values in Nigeria. Travel helps widen their horizon and appropriate other people's culture because as visitors travel to Nigeria to stay, they endeavour to meet and learn different culture and tradition of the various ethnic groups and on the other hand the tourists bring their own value system which equally influenced the environment. 
b. Tourism is a great economic development catalyst. It is a source of revenue and income generation of government, organizations and individuals. Thus, it generates foreign exchange earnings, bring about a favourable balance of payment in the international market and business in favour of the country. Visitors spending generate income through the income multiplier effect.

Tourism stimulates infrastructural development in form of good network of roads, airports, water supply, electricity, and hotels, among others. It equally brings about maintenance culture of the existing tourism infrastructure. Tourism stimulates employment opportunities because tourism trade is an important job creation avenue globally (Bhasia, 2006). The development of new infrastructure offers opportunity for job creation. Other subsector of tourism equally generates huge opportunities for citizens to be engaged in livelihood for daily living.

Akpan and Obang (2012) support that tourism

* Promotes domestic cultural developments

* National unity since tourism is human activity that thrives well in peaceful environment.

* It strengths diplomatic relations with other countries

* It equally leads to urban renewal and maintenance of clean environment.

\section{Problems of Tourism}

The prime problem of tourism is infrastructural development. Poor infrastructure hike airports access roads, electricity among others make most of the destinations inaccessible to tourist. Another important problem is that of security. Insecurity in the form of violence, kidnapping, tourism armed robbery make the destination to be unsafe for tourist. Also political ethnic and religious crises further worsen the state of insecurity, making tourists' visitation threatened.

Other effects include destructive effect on culture of the host community as youths tend to copy the way of life of the foreign tourists.

It leads to increase crime. Some hoodlums use destinations as hide out to commit serious crimes. Also, it is difficult to obtain visa among other reasons.

Thus, the place of strategic marketing becomes inevitable in the face of this unstable and unpredictable business environment. The destination managers and tourism experts have to analyze tourism market and make strategic plans that are flexible to the target market, adjustable and predictable in other to have competitive advantage over competitors and as well as confront the challenges in the environment.

Tourism is a great economic development catalyst. It is a source of revenue and income

\section{CONCLUSION}

Strategic marketing approach is very essential in tourism management and development as to analyze and predict the future of both internal and external variables of marketing environment in particular and business environment in general.

Strategic marketing application is very important in tourism since is human activity and more so a social activity that involves groups and individuals seeking leisure, business and other needs satisfaction. In essence it strives to take care of long term plans to aid the sector to grow, survive and sustained.

Key works: Marketing, Strategic marketing, Tourism, sustainability, promotion and destination. 


\section{References}

Achison, C. B. (2002) Strategic Marketing Management: An Analytical and Systematic approach, Enugu: Precision Publishers Ltd.

Adora, C.U. (2010) Managing tourism in Nigeria: The security option; in management science and Engineering 4(1) $14-25$.

Akpan, E. I. \& Obang, E.C. (2012) Tourism: A strategy for Sustainable Economic Development in Cross River State, Nigeria, International Journal of Business and Social Science 3(5) 124 - 129 3(5) 124 - 129.

Benson-Eluwa, V. (2003). Opinion Research: A Tool for public Relations. Published by Virgin Creation, Printed by Magnet Business Enterprises, Enugu.

Benson-Eluwa, V. and Joshua, Kajang (2016). Relevance of Strategic Marketing. A paper presentation.

Dalrymple, D.J. \& Parson, L.J (2000). Basic Marketing Management. New York: John Wiley \& Sons.

Ebitu, E.T (2015) Marketing Management and Strategy, Calabar: University of Calabar Press.

Esu, B.B. (2015). The Relevance of Marketing in Nigeria tourism. Development. Paper presented at the 2015

Marketing students annual conference at Michael Okpara University of Agriculture, Umudike Abia State May 15 17, 2015.

Etuk, E.J. (2003) Marketing Management dyadic interfaces; Environmental, Strategic and research imperative, for national self - reliance and development, Calabar: Skute and Associates.

Kotler, P. Brwen, J.T \& Makens J.C. (2010) Marketing for Hospitality and Tourism, New York: Pearson Educational. Lickorish, L. J \& Jenkins C.L (2003). An Introduction to Tourism, London: Butterwort Heinemann.

Page, J. \& Connell, J. (2006) Tourism: A modern synthesis, London: Thomson Learning.

Venter, P. (2009). The nature of Strategic Marketing in Venter P and Rensburg M.J.V. edited Strategic Marketing: Theory and Application for Competitive advantage, Cape Town: Oxford University Press. 